\title{
Mesenchymal Stem Cells for Cardiac Regeneration: Translation to Bedside Reality
}

\author{
Mohammad T. Elnakish,, ${ }^{1}$ Fatemat Hassan, ${ }^{2}$ Duaa Dakhlallah, ${ }^{3}$ Clay B. Marsh, ${ }^{3}$ \\ Ibrahim A. Alhaider, ${ }^{4}$ and Mahmood Khan ${ }^{2}$ \\ ${ }^{1}$ Department of Physiology and Cell Biology, The Dorothy M. Davis Heart \& Lung Research Institute, The Ohio State University, \\ Columbus, OH 43210, USA \\ ${ }^{2}$ Division of Cardiovascular Medicine, Department of Internal Medicine, The Dorothy M. Davis Heart \& Lung Research Institute, \\ The Ohio State University, Columbus, OH 43210, USA \\ ${ }^{3}$ Division of Pulmonary and Critical Care, Department of Internal Medicine, The Dorothy M. Davis Heart \& Lung Research Institute, \\ The Ohio State University, Columbus, OH 43210, USA \\ ${ }^{4}$ Department of Pharmaceutical Sciences, College of Clinical Pharmacy, King Faisal University, Al-Ahsa 31982, Saudi Arabia
}

Correspondence should be addressed to Mahmood Khan, mahmood.khan@osumc.edu

Received 23 January 2012; Accepted 3 April 2012

Academic Editor: Ettore Biagi

Copyright (C) 2012 Mohammad T. Elnakish et al. This is an open access article distributed under the Creative Commons Attribution License, which permits unrestricted use, distribution, and reproduction in any medium, provided the original work is properly cited.

Cardiovascular disease (CVD) is the leading cause of death worldwide. According to the World Health Organization (WHO), an estimate of 17.3 million people died from CVDs in 2008 and by 2030, the number of deaths is estimated to reach almost 23.6 million. Despite the development of a variety of treatment options, heart failure management has failed to inhibit myocardial scar formation and replace the lost cardiomyocyte mass with new functional contractile cells. This shortage is complicated by the limited ability of the heart for self-regeneration. Accordingly, novel management approaches have been introduced into the field of cardiovascular research, leading to the evolution of gene- and cell-based therapies. Stem cell-based therapy (aka, cardiomyoplasty) is a rapidly growing alternative for regenerating the damaged myocardium and attenuating ischemic heart disease. However, the optimal cell type to achieve this goal has not been established yet, even after a decade of cardiovascular stem cell research. Mesenchymal stem cells (MSCs) in particular have been extensively investigated as a potential therapeutic approach for cardiac regeneration, due to their distinctive characteristics. In this paper, we focus on the therapeutic applications of MSCs and their transition from the experimental benchside to the clinical bedside.

\section{Introduction}

Ischemic heart disease and congestive heart failure together are identified as the leading cause of death worldwide [1]. Myocardial infarction (MI, aka heart attack) occurs as a result of cardiomyocytes death leading to loss of viable myocytes, which lack endogenous repair mechanisms. If left untreated, it will lead to fibrous scar formation replacing the damaged myocardium with subsequent congestive heart failure (CHF) [2]. Despite, the development of a wide array of treatment options, heart failure management has failed to replace the lost cardiomyocyte mass with new contractile cells. The main challenge facing treatment options is the limited ability of the heart for self-regeneration [3]. This led to the introduction of gene- and cell-based therapeutic approaches to treat the damaged heart [4].

In an attempt to replace cardiomyocytes lost after ischemia, cellular therapy/cardiomyoplasty has been rigorously investigated in the last few years due to the potential benefits in patients with a variety of cardiac diseases such as acute MI, stable coronary artery disease, and heart failure [5]. The goals of cell-based therapies for cardiac diseases are reliant on the primary pathology, whether it is myocardial ischemia, cardiac dysfunction, or both. In myocardial ischemia, cellular transplantation is expected to provide a renewable source of proliferating, functional cardiomyocytes 
and simultaneously trigger neovascularization in order to provide a novel network of blood vessels to support and nourish the newly forming cardiomyocytes [4]. Experimental evidence has recognized numerous stem, progenitor, and mature cells that can induce these mechanisms in vivo, including embryonic stem cells (ESCs), unfractionated bone marrow cells (BMCs) and mononuclear cells (BMMNCs), hematopoietic stem cells (HSCs), mesenchymal stem cells (MSCs), endothelial progenitor cells (EPCs), cardiac progenitor cells, skeletal myoblasts, fetal cardiomyocytes, and induced pluripotent stem cells (IPSCs) [6].

Embryonic stem cells (ESCs) are derived from the inner mass of the developing embryo during the blastocyst stage. Being the prototypical stem cell, these cells have exhibited the highest potential for organ regeneration including the heart $[7,8]$. Recently, it has been reported that ESCs can differentiate into cardiac precursor cells and stimulate myocyte development [9]. On the other hand, their native propensity for pluripotent proliferation increased the risk of teratoma formation [10]. Another potential challenge for their clinical use is immunological incompatibility as a result of their allogenic origin [11]. In addition, some social and ethical concerns have been raised due to the methods by which they are obtained [8].

Unlike pluripotent embryonic stem cells, adult stem cells exhibit a limited capability of differentiation. The bone marrow represents a classic adult stem cell source, containing diverse cell populations (e.g., HSCs, EPCs and MSC) that are able to migrate and transdifferentiate into distinct phenotypes. However, the ability of these cells to differentiate into cardiac myocytes is indecisive [12-15]. Additionally, hematopoietic stem cells (HSCs) are normally recognized by the expression of $\mathrm{CD} 34^{+}$and $\mathrm{CD} 133$ cell surface markers. HSCs have been broadly investigated and successfully used clinically for bone marrow transplantation in a variety of hematologic disorders [16]. On the other hand, endothelial progenitor cells (EPCs) represent a heterogeneous population of cells that mainly exist in the bone marrow (BM). These cells are thought to induce neovascularization, possibly playing a vital role in vascular homeostasis and even myogenesis [17].

Skeletal myoblasts (SM) were the first cells to evolve into clinical trials and injected into the ischemic myocardium [18]. Despite the great potential that these cells had on MI patients, the clinical trial was shut down due to the development of serious ventricular arrhythmias in the myoblast-injected hearts [19]. Even though enhancements in left ventricular (LV) function and volumes were reported, they were not sustained [20-22]. Cardiac stem cells or progenitor cells are the other cell types that have been identified in human and mammalian hearts; these cells can be obtained from surgical or endomyocardial biopsies and clonally expanded in vitro. The exact origin of these cells whether intracardiac or extracardiac is unknown and needs to be precisely determined by lineage tracing experiments [23-27]. These cells exhibit a high proliferative potential, but this does not seem to be sufficient to heal extensive injuries as that of MI $[28,29]$. Recently a novel population of stem cells, known as induced pluripotent stem cells (iPSCs), with the characteristic properties of embryonic stem cells (ESCs) but derived from regular somatic cells such as adult fibroblasts were discovered. These human-stimulated pluripotent stem cells are developed through nuclear reprogramming, transduction of stemness factors, and the ectopic expression of pluripotency genes into fibroblasts [30-35]. This innovative approach offers an alternative source of stem cell lines with cardiogenic potential without the conflicts of using eggs or embryos [16]; however the clinical applications need to be further established [36, 37].

As described above stem cell-based therapy displays exciting promises for regenerating the damaged myocardium and treating heart failure. However, the optimal cell type to achieve this goal needs to be further investigated. MSCs, due to their distinctive characteristics properties, have been extensively investigated as an appealing therapeutic approach for cardiac regeneration. In this paper we will focus on the therapeutic applications of MSCs and their transition from the experimental benchside to the clinical bedside.

\section{Mesenchymal Stem Cells}

In the 1970s, Friedenstein et al. showed that the bone marrow contains a population of HSCs and an infrequent population of stromal cells, which are now known as mesenchymal stem cells (MSCs) [38]. They were the earliest researchers to display the capability of MSCs to differentiate into mesoderm-derived tissue and to recognize their significance in regulating hematopoiesis [39]. In the 1980s, different research groups further established that MSCs can differentiate into osteoblasts, chondrocytes, and adipocytes $[40,41]$. Later in the 1990s, Wakitani et al. demonstrated that MSCs can differentiate into a myogenic phenotype [42]. In 1999, Kopen et al. revealed that MSCs are even able to transdifferentiate into ectoderm-derived tissue [43]. In the same year, Makino et al. reported for the first time the ability of mouse BM-derived MSCs to specifically form cardiomyocytes in vitro [44], and later on Toma et al. showed the same findings in vivo [45].

Furthermore, MSCs also exert immunomodulatory effects, and they do not elicit an immune response on allogenic transplantation due to the inhibition of T-cell proliferation [46]. MSCs are shown to express HLA (human leukocyte antigen) class I, but not HLA class II on their cell surface membrane [47]. Undifferentiated as well as differentiated MSCs do not show proliferative lymphocytic immune responses upon allogenic transplantation [47]. MSCs have also been recognized for their possible role in prophylaxis and treatment of graft versus host disease [48, 49]. The immunomodulatory properties of MSCs further permit them for their clinical large-scale production and allogenic transplantation [50].

2.1. Sources, Definitions, and Types of Mesenchymal Stem Cells. MSCs have been identified in almost every tissue type such as brain, spleen, liver, kidney, lung, BM, muscle, skin, adipose tissue, thymus, aorta, vena cava, and pancreas of adult mice. MSCs might be located in all postnatal organs $[51,52]$; yet 
the most abundant source is the BM [53]. So far, there is no exact definition for MSCs; consequently, MSCs are generally defined functionally, rather than by the existence of specific surface markers [53]. MSCs adhere to cell culture dishes without expressing the surface markers that distinguish the HSCs [54]. Despite the variation in characterizing a particular phenotype among different studies, it is normally accepted that MSCs are negative for CD11b, CD14, CD31, CD34, and CD45. However, they are positive for CD29, CD44, CD73, CD105, CD106, and CD166 [2, 55-58]. MSCs are an infrequent population in the $\mathrm{BM}$, representing about $0.001-0.01 \%$ of total nucleated cells [59]. In culture they possess a spindle-shaped fibroblast-like appearance and the capability of expanding noticeably in culture, sustaining their multilineage potential [2]. These adherence criteria in culture and potential of multilineage are the most frequently established definitions of MSCs [53].

MSCs comprise several subpopulations, including, recycling stem (RS) cells, multipotent adult progenitor cells (MAPCs), human BM-derived multipotent stem cells (hBMSCs), and cardiac stem cells known as cardiac stromal cells (CStCs). Recycling stem (RS) cells represent the smallest, highly dividing group of MSCs and are thought to be the more primitive form [53]. Unlike MSCs, RS cells do not express hematopoietic stem cell surface markers, but they are unique compared to other MSCs in expressing the stem cell factor receptor (c-kit) [60]. The multipotent adult progenitor cells (MAPCs) are distinct from other MSCs in being immortal in culture. MAPCs share with human BM-derived multipotent stem cells (hBMSCs) their ability to produce cell types from all three germ layers [61, 62]. hBMSCs were shown to engraft and differentiate to multiple lineages in a rodent model of postinfarcted heart failure [63]. Recently, a trend towards using tissue specific stem cells has led to the identification of a novel type of cardiac stem cells known as cardiac stromal cells (CStCs) [64]. Rossini et al. were able to exhibit the differentiation abilities of these CStCs and the conventionally used bone-marrow-derived MSCs [64]. In this study, they showed that despite the fact that CStCs were less able to acquire the osteogenic and adipogenic phenotypes, they were able to express cardiovascular markers more efficiently. Moreover, CStC showed longer survival of transplanted cells into the infarcted heart and better ability to differentiate into cardiomyocytes than bone-marrow-derived MSCs [64].

\subsection{Therapeutic Applications of Mesenchymal Stem Cells in} Cardiac Regeneration. During the last decade, there has been growing interest in MSCs as a therapeutic approach for treating $\mathrm{MI}$, in comparison with the other cell types considered for cardiomyoplasty. MSCs have exclusive properties that may translate into convenient and extremely effective cell therapy [2]. MSCs can be easily isolated with a high expansion potential in culture providing the large numbers of cells required for transplantation within a short period of time. Their characteristic properties include the following: (1) genetic stability, (2) compatibility with tissue engineering principles, (3) reproducibility of features between different bone marrow isolates, (4) their potential to trigger regeneration in various fundamental tissues including the myocardium and neovascularization, (5) they have the ability to home to the damaged tissue or inflammatory sites, and (6) moreover their immunoregulatory properties could allow their use as an allogenic treatment. MSCs can be delivered systemically, for example, via IV injection, which simplifies administration without the necessity for cardiac catheterization laboratories. These cells can be readily transduced by a range of vectors and retain transgene expression after in vivo differentiation, which might be used eventually to enhance cell engraftment or the degree of differentiation $[2,4,53]$.

\section{Mesenchymal Stem Cell Therapy: Benchside}

In the field of MSC transplantation into cardiac tissue, animal models mostly focus on fate, efficacy, regenerative mechanisms, and the safety of transplanted MSCs. In line with the increased incidence of myocardial infarction, both small and large animal models have been used in large numbers, providing the proof of functional effectiveness, pathomechanisms, and safety of MSC transplantation [65]. In this context, it has been reported that BM cells were used for the first time for cardiomyoplasty in 1999 by the laboratories of Tomita et al. [66]. In this paper, rats received autologous BMCs via direct intramyocardial injection at 3 weeks after cryoinjury. Eight weeks postcryoinjury researchers were able to identify transplanted BMCs in all animals. They found that these cells expressed muscle-specific proteins that were absent prior to implantation. Moreover, they reported improvements in systolic and diastolic functions in animals that received cells pretreated with the DNA-demethylating agent 5-azacytidine (5-Aza), which has been established to augment myogenic differentiation of pluripotent stem cells [44]. Thereafter, numerous preclinical studies reported improvement of left ventricular (LV) function, decreased infarct size, and decreased mortality rate after transplantation of MSCs in mice [65, 67-71], rats [72-79], swine [80$92]$, canine $[93,94]$, and sheep $[78,95]$ after acute or chronic MI. These enhancements were observed even with minimal percentage of cells exhibiting cardiomyocytes differentiation $[65,70,94]$ (Table 1).

Due to the anatomical similarity to the human heart, swine heart has been chosen as a model for studies related to MI and general cardiovascular studies [96]. This model has been used to acquire significant information on the tracking of transplanted MSCs in healthy and infracted myocardium and the immediate and long-term effects after engraftment [97]. In the swine model, Shake et al. reported strong engraftment of labeled MSCs along with coexpression of numerous muscle-specific proteins as early as two weeks after intramyocardial implantation. This study proposed that the differentiation of MSCs into cardiomyocytelike cells occurs two weeks after transplantation, followed by a significant improvement of contractile dysfunction and wall thinning [92]. A similar study by Schuleri et al. showed that intramyocardial transplantation of MSCs 
TABLE 1: Effects of MSC therapy on both small and large animal models of MI. MI, myocardial infarction; DI, direct intramyocardial injection; IV, intravenous infusion; IS, in situ injection; TESI, transendocardial stem cell injection; IC, intracoronary infusion; LV, left ventricular; EF, ejection fraction; ESV, end-systolic volume; EDV, end-diastolic volume; $\uparrow$, increase; $\downarrow$, decrease. ${ }^{*}$ The monolayered cell graft was placed on a plastic sheet and applied face down onto the surface of the infarct area. The plastic sheet was then carefully removed, leaving the monolayered cell graft on the surface of the heart.

\begin{tabular}{|c|c|c|c|}
\hline $\begin{array}{l}\text { Species/model } \\
\text { Mice }\end{array}$ & Dose & Results & Reference \\
\hline Acute MI & $0.5-5 \times 10^{5}(\mathrm{DI})$ & $\downarrow$ Both infarct size and fibrosis at 2 weeks & Kudo et al. [68] \\
\hline Acute MI & $3 \times 10^{5}(\mathrm{DI})$ & $\uparrow$ Cardiac function at 4 weeks & Fazel et al. [65] \\
\hline Acute MI & $5 \times 10^{5}(\mathrm{DI})$ & $\downarrow$ Infarct size; $\uparrow$ cardiac function at 3 days & Noiseux et al. [70] \\
\hline Acute MI & $1 \times 10^{6}(\mathrm{DI})$ & $\uparrow$ LVEF at 2 and 4 weeks & Nakamura et al. [69] \\
\hline Acute MI & $1 \times 10^{6}(\mathrm{DI})$ & $\uparrow$ Cardiac function at 1 month & Shiota et al. [71] \\
\hline Acute MI & $2 \times 10^{5}(\mathrm{DI})$ & $\uparrow \mathrm{LVEF}$ and LV function at 2 weeks & Grauss et al. [67] \\
\hline \multicolumn{4}{|l|}{ Rats } \\
\hline Acute MI & $5 \times 10^{6}(\mathrm{DI})$ & $\downarrow$ Cardiac remodeling; $\uparrow$ cardiac performance at 2 weeks & Mangi et al. [77] \\
\hline Acute MI & $5 \times 10^{6}(\mathrm{IV})$ & $\uparrow$ Cardiac function; $\downarrow$ infarct size at 4 weeks & Nagaya et al. [79] \\
\hline Acute MI & $2 \times 10^{6}(\mathrm{DI})$ & Transient global LV function improvement at 4 weeks & Dai et al. [73] \\
\hline Acute MI & $2 \times 10^{6}(\mathrm{DI})$ & $\downarrow$ Fibrosis; $\uparrow$ cardiac function at 8 weeks & Berry et al. [72] \\
\hline Acute MI & Cell graft ${ }^{*}$ & Reversed wall thinning; $\uparrow$ cardiac function at 8 weeks & Miyahara et al. [78] \\
\hline Acute MI & $6 \times 10^{6}(\mathrm{DI})$ & $\uparrow$ LVEF; $\downarrow$ infarct size at 3 weeks & Li et al. $[76]$ \\
\hline Acute MI & $1 \times 10^{6}($ IS $)$ & $\uparrow$ LVEF; $\downarrow$ infarct size at 30 days & $\begin{array}{l}\text { de Macedo Braga et } \\
\text { al. [74] }\end{array}$ \\
\hline Acute MI & $5 \times 10^{6}(\mathrm{DI})$ & $\uparrow$ LVFS; $\downarrow$ fibrosis at 4 weeks & Imanishi et al. [75] \\
\hline \multicolumn{4}{|l|}{ Swine } \\
\hline Subacute MI & $6 \times 10^{7}(\mathrm{DI})$ & $\downarrow$ Wall thinning in the scar area; $\uparrow$ cardiac function at 4 weeks & Shake et al. [92] \\
\hline Acute MI & $2 \times 10^{8}(\mathrm{TESI})$ & $\downarrow$ Necrotic myocardium; $\uparrow$ cardiac performance over 8 weeks & Amado et al. [80] \\
\hline Chronic MI & $2 \times 10^{8}(\mathrm{DI})$ & Preserved LVEF at 60 and 90 days post-MI & Makkar et al. [86] \\
\hline Acute MI & $2 \times 10^{8}(\mathrm{TESI})$ & $\downarrow$ Infarct size at 1 and 8 weeks; restored contractile function & Amado et al. [81] \\
\hline Acute MI & $3.2 \times 10^{8}(\mathrm{IV})$ & $\uparrow$ LVEF; $\downarrow$ hypertrophy at 3 months & Price et al. [87] \\
\hline Subacute MI & $6.3 \times 10^{5}(\mathrm{TESI})$ & $\downarrow$ Scar size; $\downarrow$ EDV; $\uparrow$ LVEF at 10 days & Gyongyosi et al. [82] \\
\hline Chronic MI & $1-10 \times 10^{6}(\mathrm{IV})$ & $\begin{array}{l}\uparrow \text { Vasculogenesis; } \uparrow \text { regional perfusion; no change in LVEF at } \\
12 \text { weeks }\end{array}$ & Halkos et al. [83] \\
\hline Acute MI & $0.24-4.4 \times 10^{8}(\mathrm{TESI})$ & $\downarrow$ Scar size; no change in LVEF at 12 weeks & Hashemi et al. [84]. \\
\hline Acute MI & $1 \times 10^{7}(\mathrm{IC})$ & $\uparrow \mathrm{EF} ; \downarrow$ scar size at 8 weeks & Qi et al. [88] \\
\hline Acute MI & $2 \times 10^{8}(\mathrm{TESI})$ & $\uparrow$ Myocardial blood flow at 1 week; $\uparrow$ LV function at 8 weeks & Schuleri et al. [90] \\
\hline Chronic MI & $2 \times 10^{8}(\mathrm{TESI})$ & $\begin{array}{l}\downarrow \text { Scar size; } \uparrow \text { EF; } \uparrow \text { regional contractility; } \uparrow \text { myocardial } \\
\text { perfusion over } 12 \text { weeks }\end{array}$ & Quevedo et al. [89] \\
\hline Chronic MI & $0.2-2 \times 10^{8}(\mathrm{DI})$ & $\begin{array}{l}\downarrow \text { Scar size; } \uparrow \text { EF; } \uparrow \text { regional contractility; } \uparrow \text { myocardial } \\
\text { perfusion at } 12 \text { and } 24 \text { weeks }\end{array}$ & Schuleri et al. [91] \\
\hline Acute MI & $0.75-1 \times 10^{8}(\mathrm{TESI})$ & $\downarrow$ Scar size; $\uparrow$ EF at 2 and 8 weeks & $\begin{array}{l}\text { Hatzistergos et al. } \\
{[85]}\end{array}$ \\
\hline \multicolumn{4}{|l|}{ Canine } \\
\hline $\begin{array}{l}\text { Chronic } \\
\text { ischemia }\end{array}$ & $1 \times 10^{8}(\mathrm{DI})$ & $\downarrow$ Fibrosis; $\uparrow$ LVEF at 60 days & Silva et al. [94] \\
\hline Subacute MI & $1 \times 10^{8}(\mathrm{IC} / \mathrm{TESI})$ & $\begin{array}{l}\uparrow \mathrm{EF} ; \downarrow \text { myocardial ischemia; } \downarrow \text { EDV and ESV at } 21 \text { days } \\
\text { post-MI }\end{array}$ & Perin et al. [93] \\
\hline \multicolumn{4}{|l|}{ Sheep } \\
\hline Acute MI & $25-450 \times 10^{6}(\mathrm{DI})$ & $\begin{array}{l}\downarrow \text { Infarct expansion; } \uparrow \text { vascular density in the border zone; } \uparrow \\
\text { EF; } \downarrow \text { EDV at } 8 \text { weeks }\end{array}$ & Hamamoto et al. [95] \\
\hline
\end{tabular}


resulted in a significant increase of LV function eight weeks after transplantation [90]. These improvements were preceded by an early enhancement of resting myocardial blood flow after one week, which was confirmed by an increase in vessel size in the MSC group versus the control groups. These observations suggest that transplantation of MSCs can ameliorate cardiac function by reducing infarct size, triggering neovascularization and cardiomyogenesis (Table 1).

The optimization of safety and possible procedures for cell delivery are central issues to be considered in cardiomyoplasty. By using large animal models (i.e., swine, dogs, sheep), the majority of investigators have revealed that the intramyocardial injection of progenitor cells across the infarcted region is safe and possible [97]. For example, experiments on the swine model showed that intramyocardial injection of MSCs (range: $10^{4}-10^{8}$ cells) is safe and does not result in any obvious immune or toxic response [92, 96, 98-100]. On the other hand, studies on dosedependent effects have displayed no relevant results to date [84]. Also, "off the shelf" application of allogenic MSCs in a swine safety study with repeated intramyocardial injections of high doses of MSCs (up to $800 \times 10^{6}$ cells) was devoid of adverse effects in terms of sustained ventricular arrhythmia, anaphylaxis, or myocardial damage [101]. Additionally, the procedural safety of the intramyocardial injection process was demonstrated in a canine chronic ischemia model. Dogs that received intramyocardial injections of MSCs $\left(1 \times 10^{8}\right.$ total cells) tolerated the procedure without exhibiting any complications such as cardiac arrhythmias or myocardial damage [94].

On the other hand, intravenous infusion of MSCs in swine changed the electrophysiological properties of the myocardium [87]. In this study, there was significant increase in cardiac function and decrease in eccentric hypertrophy; however, there was also a shortening in epicardial effective refractory periods in MSC-treated animals in comparison with placebo. Shortened effective refractory periods might trigger ventricular tachycardia [102] and increase the possibility of MSCs to trigger proarrhythmic remodeling. In contrast to these observations in swine, intravenous infusion of allogenic MSCs in humans with acute MI revealed fewer ventricular arrhythmias than in those with placebo infusion [103]. These studies revealed that intravenous allogenic MSCs are safe in patients with acute MI. Likewise, MSC therapy in other clinical trials was not associated with any adverse effects [104, 105].

In addition to cardiac arrhythmia and myocardial damage, a number of reports have raised concerns about tumor formation as a result of using BM-cultured MSCs. In these reports murine-derived BM-MSCs exhibited chromosomal abnormalities that led to tumor formation in many organs [106, 107]. In addition, a recent report revealed that both MSCs and BM-derived stem cells have been associated with calcification and probably ossification of the heart in a murine model of MI [108]. In contrast to these observations, numerous large-animal preclinical studies displayed the safety of MSCs therapy and are devoid of tumor formation or ectopic tissue growth [80, 81, 83-87, 90, 91, 94]. Moreover, data from early-phase human studies using MSCs showed no evidence of ectopic tissue growth [103-105]. Even so, the data of tumorigenesis in murine models emphasizes the necessity of persistent long-term monitoring of patients treated with MSCs. Furthermore, other reports have shown that intracoronary injection of MSCs in canine and swine models of MI resulted in microinfarctions and slow coronary arterial flow, respectively $[109,110]$. Microvascular obstruction with intracoronary MSCs injection may be explained by the fact that the size of MSCs is larger than other stem cell types and their characteristic adherence to plastic in vitro [53]. Nonetheless, this does not appear to be a problem in the limited clinical experience, so far [53].

In summary, MSC therapy has been shown to be safe and effective in improving LV function, decreasing scar size, and increasing myocardial tissue perfusion and angiogenesis in post-MI small and large animal models. Yet, it is hard to evaluate the impact of these preclinical studies on MI patients. In regard to effectiveness of MSCs, data displaying a time-dependent retention, engraftment, migration, and differentiation support the notion that MSC implantation is an alternative therapeutic approach for ischemic heart failure [97]. Considering procedural safety, it could be presumed that the reliable security findings displayed by the swine studies may be applicable to humans [111]. Nevertheless, it is clear that further studies are needed.

3.1. Modification of Mesenchymal Stem Cells for Cardiac Therapy. Regardless of the benefits of MSCs, clinical application of MSC-based therapy is restricted. This restriction is attributed to the poor viability of the transplanted cells in the myocardium [29]. Recent reports on a swine model of MI displayed that only 5\% of implanted MSCs can survive for 14 days in the infracted myocardium [109]. In addition, Toma et al. showed that the survival rate of the implanted hMSCs in an intact mouse heart is less than $0.5 \%$ at 4 days after transplantation [45]. Analogous outcomes were also obtained from studies using diverse cell types. Accordingly, cell viability posses a major obstacle for any cellbased therapeutic strategy in the infarct heart [29]. Secondly, reactive oxygen species (ROS) is known to be a key mediator in cardiac dysfunction. ROS is known to hinder cell adhesion and stimulate cell detachment and death [112-115]. Third, the grafted cell may encounter ischemic conditions lacking nutrients and oxygen and consequently affecting cell viability $[116,117]$. On the other hand, myocardial injury has been shown to generate a strong inflammatory response followed by production of oxygen-derived free radicals and inflammatory cytokines that trigger cell death and initiate apoptosis [118]. Despite all these, MSCs may react differently in the allogenic settings due to their previously described immunomodulatory effects on inflammatory cells [29].

To overcome the low cellular survival and transdifferentiation strength of MSCs after transplantation, several strategies have been proposed for MSCs manipulation (Figure 1). Pretreatment with growth and differentiation factors to expand the stem cells and facilitate their engraftment into cardiac tissues has been attempted $[25,119-$ 121]. Also pretreatment with pharmacological agents such as 
estrogen, which influences myocardial remodeling through stimulating growth hormone production in BM-MSCs and EPCs [122] or through atorvastatin which enhances cell survival and differentiation into cardiomyocytes [123]. More recently, our group has demonstrated that combined treatment of rats with stem cells and pharmacological hyperbaric oxygen $(\mathrm{HBO})$ treatment led to enhanced cell engraftment and decreased fibrosis at four weeks after transplantation $[55,124]$. Furthermore, stem cell preconditioning prior to transplantation, such as hypoxic preconditioning, has been shown to activate the Akt signaling pathway and the heat shock protein (Hsp-70), therefore, maintaining cell viability and cell cycle rates $[125,126]$. Moreover, overexpression of anti-cell-death signals or signals that improve cell adhesion resulted in better recovery and adhesion after transplantation [76, 77, 127-137].

Additionally, recent studies have shown that microRNAs (miRNAs) are one of the key modulators in stem cell differentiation. MiRNAs regulate gene expression in stem cells that control its fate, function, and behavior. The most important change in ESCs by miRNAs is the cell differentiation, it was shown that $m i R-21, m i R-134$, and $m i R-$ 470 target certain genes to promote cell differentiation [138140]. At the same time, stem cell transcription factors and silencing complexes bind to miRNAs promoter region and regulate their expression during early cellular differentiation. In murine ESCs, the most abundant miRNAs was miR-17-92 cluster and $m i R-302$ that have been key regulators of cellular proliferation [141-143]. It is worth mentioning that these miRNAs are involved in maintaining DNA methylation and facilitating repression and overexpression of certain genes through differentiation and development [144]. Recent findings have shown that $m i R-150$ regulates the mobilization and migration of bone marrow mononuclear cells by targeting CXCR4 [145].

\section{Mesenchymal Stem Cell Therapy: Bedside}

For any particular type of cell-based therapy to be translated from the preclinical benchside to the clinical bedside, Murry et al. [146] proposed specific criteria; first preclinical revelation of safety and efficacy should be evident reproducibly in manifold laboratories. The inability of professionals in a well-controlled laboratory to reproduce certain finding means that the probability of such treatment to succeed in the more capricious world of human clinical trials is low, understanding the mechanisms of action to a logical extent is also necessary, and especially the mechanisms by which cell therapy causes functional improvements will help in designing rational experimental and/or clinical studies to improve the treatment effectiveness. Cell-based therapy should be validated in a scaled-up, physiologically pertinent large animal model whenever possible. Regardless of the advantages of small animals, several features of human cardiovascular physiology cannot be reproduced in these animal models. For instance, recognition of pacemaker activity in stem cell transplants could be prevented by the high heart rate of mice or rats, while implanting the same cells into a larger animal model such as dogs, pigs, or sheep could allow the detection of such complications [146].

Although the exact mechanisms of MSCs therapy are not well defined, prosperity of preclinical studies showing the feasibility, efficacy, and safety of such therapy as mentioned above paved their way to enter the clinical trials for human cardiac regeneration. However, variations among different laboratories in using diverse sources of tissues, methods of extraction, protocols for culturing, and tools for characterization led to many debates about the characteristics and potencies of MSCs. These disparities may cause isolation and expansion of distinct subpopulations of cells or may alter the cell characteristics [147]. For example, comparing MSCs cultivated in human supplements to those cultured in fetal bovine serum (FBS) demonstrated that FBS modifies the expression of genes involved in differentiation and adhesion/extracellular matrix to some extent [50, 147]. Furthermore, insufficiency of MSCs regularly necessitates ex vivo expansion; however, widespread expansion may result in futile or collapsed cells [148].

Further, clinical trials using MSCs that are obtained and characterized by a number of diverse protocols may limit the reproduction or the elucidation of the clinical findings [149]. Therefore, the challenge for researchers intending to produce MSCs for clinical trials is to delineate the finest cell culture conditions for efficient isolation and ex vivo expansion of homogenous MSCs along with maintaining the cellular characteristics needed for the planned clinical application and diminishing possibilities of undesirable side effects at the same time [50]. This requires that the whole MSC manufacturing process from starting material until potency testing for the planned clinical application should be extremely standardized to obtain the required and reproducible cellular characteristics and potencies [50]. In this regard, using adult stem cell types in clinical studies, normally, needs formal approval by the respective regulatory body. This approval entails that cellular products should be manufactured, processed, and tested according to the present national guidelines, including present good tissue practice (GTP), good manufacturing practice (GMP), and good clinical practice (GCP). Applying these regulatory frameworks on the cellular products will guarantee the safety, purity, and potency of these products and the feasibility of their use in clinical application [50].

In comparison with the BMCs, the clinical involvement of MSCs for cardiac regeneration remains in its early stages and only a few number of phase I/II clinical studies have been reported [150]. Table 2 summarizes some of the MSC clinical trials in different cardiac pathologies including MI, chronic ischemia, and heart failure. In 2004, Chen et al. [104] investigated for the first time the outcomes of intracoronary injection of autologous BM-MSCs $\left(8-10 \times 10^{9}\right.$ cells $)$ in acute MI patients. At three-month followup, marked enhancements in myocardial perfusion, LV ejection fraction, and LV chamber dimensions were evident in MSC-treated patients in comparison with placebo. Notably, this paper displayed that MSC therapy is safe and devoid of deaths and arrhythmias during the follow-up period. Similarly, in 2005, Katritsis et al. [151] investigated the effect of 


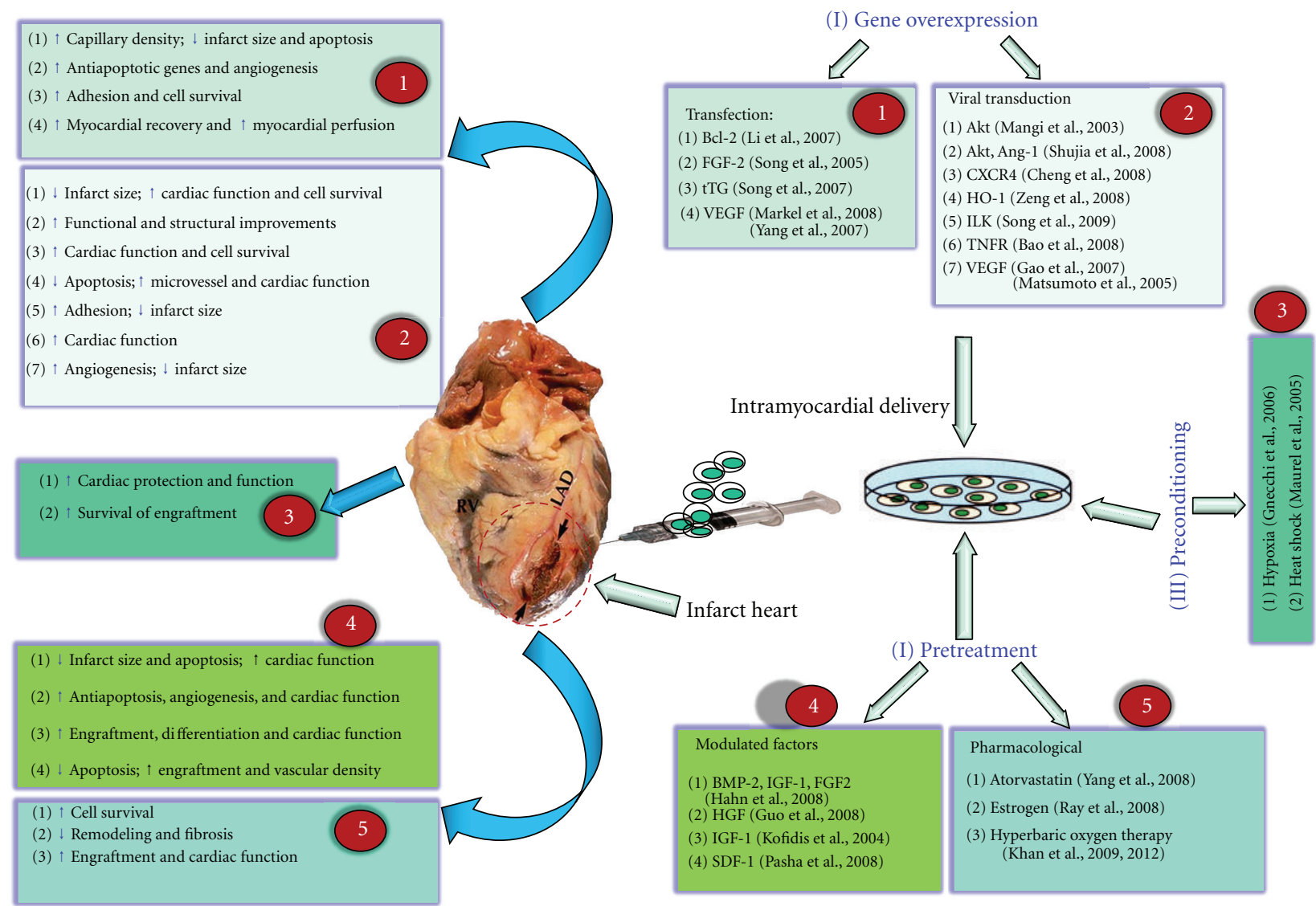

FIGURE 1: Illustration of MSC modifications and its effect after transplantation on engraftment, cell survival, apoptosis, cardiac function, fibrosis, and angiogenesis in animal models of MI.

TABLE 2: MSC clinical trials in MI, chronic ischemia, and heart failure. MI, myocardial infarction; IC, intracoronary infusion; DI, direct intramyocardial injection; IV, intravenous infusion; TESI, transendocardial stem cell injection; EMG; electromechanical guidance; LV, left ventricular; EF, ejection fraction; ESV, end-systolic volume; EDV, end-diastolic volume; $\uparrow$, increase; $\downarrow$, decrease.

\begin{tabular}{|c|c|c|c|c|}
\hline Group & Condition & Dose (cells) & $\begin{array}{l}\text { Followup } \\
\text { (months) }\end{array}$ & Results \\
\hline Chen et al. [104] & Acute MI & $8-10 \times 10^{9}(\mathrm{IC})$ & 3 & $\begin{array}{c}\uparrow \text { Myocardial perfusion, } \uparrow \\
\text { LVEF, and } \downarrow \text { LV chamber } \\
\text { dimensions }\end{array}$ \\
\hline Katritsis et al. [151] & Anteroseptal MI & $2-4 \times 10^{6}(\mathrm{IC})$ & 4 & $\begin{array}{c}\downarrow \text { Wall motion score index } \\
\text { and } \uparrow \text { myocardial viability } \\
\text { and contractility }\end{array}$ \\
\hline $\begin{array}{l}\text { Mohyeddin-Bonab et al. } \\
\text { [153] }\end{array}$ & Old MI & $2.1-9.1 \times 10^{6}(\mathrm{IC}) /(\mathrm{DI})$ & $6-18$ & $\begin{array}{c}\downarrow \text { Perfusion defect and } \uparrow \\
\text { LVEF }\end{array}$ \\
\hline Osiris therapeutics [146] & Acute MI & (IV) & 6 & $\begin{array}{l}\uparrow \text { Heart function and } \downarrow \\
\text { arrhythmic events }\end{array}$ \\
\hline Hare et al. [103] & Acute MI & $0.5,1.6$, and $5 \times 10^{6}(\mathrm{IV})$ & 3 & $\begin{array}{l}\uparrow \text { LVEF and } \downarrow \text { ventricular } \\
\text { arrhythmia }\end{array}$ \\
\hline Williams et al. [105] & $\begin{array}{l}\text { Chronic ischemic } \\
\text { cardiomyopathy secondary to MI }\end{array}$ & $\begin{array}{l}10 \text { repeated injections of } 0.5 \mathrm{~mL} \\
\text { of cell suspension (TESI) }\end{array}$ & $3-12$ & $\begin{array}{l}\downarrow \text { Cardiac remodeling, } \downarrow \\
\text { ESV and EDV, and } \uparrow \\
\text { regional contractility }\end{array}$ \\
\hline $\begin{array}{l}\text { Bartunek et al. [154] } \\
\text { (C-CURE) }\end{array}$ & $\begin{array}{l}\text { Heart failure secondary to } \\
\text { ischemic cardiomyopathy }\end{array}$ & $6-12 \times 10^{8}(\mathrm{EMG})$ & 6 & $\uparrow \mathrm{LVEF}$ and $\downarrow$ ESV and EDV \\
\hline
\end{tabular}


a combination of intracoronary transplantation of BMderived MSCs and EPCs $\left(2-4 \times 10^{6}\right.$ cells $)$ on tissue repair in myocardial scars of patients with an anteroseptal MI. At four-month followup, they reported a significant decrease in wall motion score index and significant increases in myocardial viability and contractility in stem-cell treated patients compared to untreated controls. Moreover, the investigators chose only five patients into their series who had implantable cardioverter defibrillator (ICD) to examine the potential proarrhythmic effect of MSC therapy [152]. At 16-36-month followup, assessment of the ICD showed that none of the MSCs-treated exhibited either sustained or nonsustained ventricular arrhythmia. Finally, they concluded that intracoronary transplantation of MSCs and EPCs is feasible, safe, and may participate in regional myocardial regeneration following $\mathrm{MI}$.

Mohyeddin-Bonab et al. [153] investigated the safety and feasibility of MSCs therapy in a pilot study of eight patients with old MI. MSCs (2.1-9.1 × $10^{6}$ cells) were injected either intracoronary in patients undergoing revascularization by percutaneous coronary intervention or by direct epicardial injection in patients undergoing revascularization by coronary artery bypass graft surgery. At 6-18-month followup, they revealed smaller perfusion defect, better LV ejection fraction, and enhanced heart failure functional class without reporting any adverse side effects. Therefore, MSC therapy was described to be safe and feasible in patients with old MI. In 2008, Osiris Therapeutics [146] announced the preliminary results of the first clinical trial of MSC transplantation for cardiac regeneration in the United States. Patients received allogenic MSCs transplants by intravenous infusion. At 6-month followup, MSC-treated patients exhibited improvement in the heart and lung function along with decreased arrhythmic events compared to placebo group. The researchers reported that such allogenic cell products did not necessitate prolonged cell pretreatment handlings; however they are readily accessible to fulfill the clinical community requirements [150]. A recent study by Hare et al. [103] performed a double-blind, placebo-controlled, dose-ranging $\left(0.5,1.6\right.$, and $5 \times 10^{6}$ cells $\left./ \mathrm{kg}\right)$ safety trial of intravenous allogenic MSCs in acute MI patients. Results of this study demonstrated the safety of such intervention in post-MI patients. It also demonstrated a decrease in ventricular arrhythmias, enhanced pulmonary function, and increased LV ejection fraction in MSC-treated patients after 3 months.

In 2011, Williams et al. [105] examined the functional effects of transendocardial injection of MSCs in patients with chronic ischemic cardiomyopathy secondary to MI. In this study MSC-treated patients exhibited decreased cardiac remodeling and enhanced regional contractility along with decreased end-diastolic and end-systolic volumes, at 3 months following stem cell injection and continued up to one year. Notably, there was no evidence of ectopic tissue growth or sustained arrhythmias at one year after transplantation. This data indicates not only the safety of MSC therapy for post-MI transplantation but also the efficacy of such therapy in modulating cardiac structure and function. Most recently, Bartunek et al. [154] reported the results of the C-CURE clinical trial for the treatment of ischemic cardiomyopathy. In this study, guided cardiopoietic-MSC therapy was delivered to viable but defective myocardium by electromechanical guidance. At 6-month followup, the results showed significant enhancements in clinical performance and ejection fraction, compatible with improvement in end-diastolic and end-systolic volumes in cardiopoieticMSC therapy group compared to controls. Importantly, evidence of cardiopoietic MSC-induced arrhythmias or toxicity was absent.

Furthermore, a number of other clinical trial efforts are on track. Consistent with the registered data from http://www.clinicaltrials.gov, a web-based service by the National Institutes of Health of the United States, there are ten ongoing phase I/II trials to evaluate the efficacy and/or safety of MSCs therapy for cardiac regeneration in diverse places in the world including the United States, Europe, and East and South Asia (Table 3). These studies are using different interventions for applying autologous and/or allogenic MSCs in the treatment of different cardiac pathologies such as acute MI, chronic ischemic LV dysfunction secondary to $\mathrm{MI}$, and nonischemic dilated cardiomyopathy.

\section{Future Perspectives of Mesenchymal Stem Cell Therapy}

Overall, preclinical and clinical data from animal models and humans have demonstrated the feasibility, safety, and efficiency of MSCs therapy for cardiac regeneration. Accordingly, MSC therapy assures myocardial repair for a large number of heart failure patients; yet, there are several aspects that still need to be resolved. This will need rigorous investigation in the years to come [53]. Future studies should focus on the efficiency of MSC therapy in animals at different ages (adult and old), instead of young adult animals only. Investigating the efficacy of MSC treatment combined with standard post-MI therapies, such as angiotensin converting enzyme inhibitors and beta-blockers, is also necessary to maximize the therapeutic benefits. Subsequently, dose escalation studies will be required to optimize MSC therapy before being considered as a potential clinical treatment. It is also important to consider the potential benefits of MSC therapy in nonischemic heart failure models rather than the commonly used post-MI model [53]. Approaches to improve engraftment and differentiation are required due to the low retention of cardiac stem cells regardless of the delivery method used. Moreover, the precise mechanism of action of MSCs needs to be specifically defined; it is still not clear if they work through paracrine signaling, cell fusion, cell-cell interaction, differentiation to cardiomyocytes, neovascularization, and/or a combination of some or all of these effects.

\section{Conflict of Interests}

The authors declared that there is no conflict of interests. 
TABLE 3: Ongoing clinical trials on MSCs: condition, intervention/dose, and followup in patients around the world (http://www.clinicaltrials.gov).

\begin{tabular}{|c|c|c|c|c|}
\hline World & Condition & Intervention & Time frame & Phase/Status \\
\hline \multirow{4}{*}{ Florida (USA) } & $\begin{array}{l}\text { Chronic ischemic LV } \\
\text { dysfunction secondary to MI }\end{array}$ & $\begin{array}{l}10 \text { and } 20 \text { intramyocardial injections } \\
\text { of } 2 \text { million MSCs (low dose) or } 20 \\
\text { million (high dose) } / 0.25-0.5 \mathrm{~cm}^{3} \text { for a } \\
\text { total of } 20 \text { million or } 200 \text { million cells, } \\
\text { respectively }\end{array}$ & 6-18 months & Phase I/II (unknown) \\
\hline & $\begin{array}{l}\text { Chronic ischemic LV } \\
\text { dysfunction and heart failure } \\
\text { secondary to MI }\end{array}$ & $\begin{array}{l}\text { Transendocardial injection of } \\
\text { autologous human cells (bone marrow } \\
\text { or mesenchymal). } 40 \text { million cells } / \mathrm{mL} \\
\text { delivered in either a dose of } \\
0.25 \mathrm{~mL} / \text { injection for a total of } 100 \\
\text { million } \times 10 \text { injections or a dose of } \\
0.5 \mathrm{~mL} / \text { injection for a total of } 200 \\
\text { million } \times 10 \text { injections }\end{array}$ & $6-18$ months & Phase I/II (unknown) \\
\hline & $\begin{array}{l}\text { Chronic ischemic LV } \\
\text { dysfunction secondary to MI }\end{array}$ & $\begin{array}{l}\text { Transendocardial injection of } \\
\text { autologous versus allogeneic MSCs. } 40 \\
\text { million cells/mL delivered in either a } \\
\text { dose of } 0.5 \mathrm{~mL} / \text { injection } \times 1 \text { injection } \\
\text { for a total of } 20 \text { million, a dose of } \\
0.5 \mathrm{~mL} / \text { injection } \times 5 \text { injections for a } \\
\text { total of } 100 \text { million, or a dose of } \\
0.5 \mathrm{~mL} / \text { injection } \times 10 \text { injections for a } \\
\text { total of } 200 \text { million MSCs }\end{array}$ & $6-13$ months & Phase I/II (active) \\
\hline & $\begin{array}{l}\text { Nonischemic dilated } \\
\text { cardiomyopathy }\end{array}$ & $\begin{array}{l}\text { Transendocardial injection of } \\
\text { autologous versus allogeneic MSCs. } 20 \\
\text { million cells } / \mathrm{mL} \text { delivered in a dose of } \\
0.5 \mathrm{~mL} / \text { injection } \times 10 \text { injections for a } \\
\text { total of } 100 \text { million of MSCs }\end{array}$ & $6-12$ months & Phase I/II (active) \\
\hline \multirow[b]{2}{*}{ Maryland (USA) } & $\begin{array}{l}\text { Chronic ischemic LV } \\
\text { dysfunction secondary to MI }\end{array}$ & $\begin{array}{l}10 \text { and } 20 \text { intramyocardial injections } \\
\text { of } 2 \text { million MSCs (low dose) or } 20 \\
\text { million (high dose) } / 0.25-0.5 \mathrm{~cm}^{3} \text { for a } \\
\text { total of } 20 \text { million or } 200 \text { million of } \\
\text { autologous human MSCs, respectively }\end{array}$ & $6-18$ months & Phase I/II (unknown) \\
\hline & $\begin{array}{l}\text { Chronic ischemic LV } \\
\text { dysfunction secondary to MI }\end{array}$ & $\begin{array}{l}\text { Transendocardial injection of } \\
\text { autologous versus allogeneic MSCs. } 40 \\
\text { million cells } / \mathrm{mL} \text { delivered in either a } \\
\text { dose of } 0.5 \mathrm{~mL} / \text { injection } \times 1 \text { injection } \\
\text { for a total of } 20 \text { million, a dose of } \\
0.5 \mathrm{~mL} / \text { injection } \times 5 \text { injections for a } \\
\text { total of } 100 \text { million, or a dose of } \\
0.5 \mathrm{~mL} / \text { injection } \times 10 \text { injections for a } \\
\text { total of } 200 \text { million MSCs }\end{array}$ & 6-13 months & Phase I/II (active) \\
\hline France (Europe) & $\begin{array}{l}\text { Chronic myocardial ischemia; } \\
\text { LV dysfunction }\end{array}$ & $\begin{array}{l}\text { Transendocardial intramyocardial } \\
\text { injections of } 60 \text { million autologous } \\
\text { MSCs }\end{array}$ & 30 days -2 years & Phase I/II (active) \\
\hline China (East Asia) & ST-elevation MI & $\begin{array}{l}\text { Intracoronary human umbilical } \\
\text { WJ-MSC transfer }\end{array}$ & 4 months-1 year & Phase II (active) \\
\hline Korea (East Asia) & Acute MI & $\begin{array}{l}\text { Intracoronary injection of single dose } \\
\text { of autologous bone-marrow-derived } \\
\text { MSCs (I million) cells/kg }\end{array}$ & 6 months & Phase II (completed) \\
\hline India (South Asia) & ST-elevation acute MI & $\begin{array}{l}\text { A Single Dose of Intravenous infusion } \\
\text { of Allogenic MSCs }\end{array}$ & 6 months & Phase I/II (active) \\
\hline
\end{tabular}




\section{Acknowledgment}

The authors would like to acknowledge funding from AHASDG (0930181N) and CCTS (UL1RR025755).

\section{References}

[1] S. Mendis, P. Puska, and B. Norrving, Global Atlas on Cardiovascular Disease Prevention and Control, World Health Organization, Geneva, Switzerland, 2011.

[2] M. F. Pittenger and B. J. Martin, "Mesenchymal stem cells and their potential as cardiac therapeutics," Circulation Research, vol. 95, no. 1, pp. 9-20, 2004.

[3] G. C. Fonarow, "Heart failure: recent advances in prevention and treatment," Reviews in Cardiovascular Medicine, vol. 1, no. 1, pp. 25-54, 2000.

[4] P. J. Psaltis, A. C. W. Zannettino, S. G. Worthley, and S. Gronthos, "Concise review: mesenchymal stromal cells: potential for cardiovascular repair," Stem Cells, vol. 26, no. 9, pp. 2201-2210, 2008.

[5] L. G. Melo, A. S. Pachori, D. Kong et al., "Molecular and cellbased therapies for protection, rescue, and repair of ischemic myocardium: reasons for cautious optimism," Circulation, vol. 109, no. 20, pp. 2386-2393, 2004.

[6] M. A. Laflamme and C. E. Murry, "Regenerating the heart," Nature Biotechnology, vol. 23, no. 7, pp. 845-856, 2005.

[7] R. Gulati and R. D. Simari, "Cell Therapy for Acute Myocardial Infarction," Medical Clinics of North America, vol. 91, no. 4, pp. 769-785, 2007.

[8] A. G. Smith, "Embryo-derived stem cells: of mice and men," Annual Review of Cell and Developmental Biology, vol. 17, pp. 435-462, 2001.

[9] J. Y. Min, Y. Yang, M. F. Sullivan et al., "Long-term improvement of cardiac function in rats after infarction by transplantation of embryonic stem cells," Journal of Thoracic and Cardiovascular Surgery, vol. 125, no. 2, pp. 361-369, 2003.

[10] D. Solter, "From teratocarcinomas to embryonic stem cells and beyond: a history of embryonic stem cell research," Nature Reviews Genetics, vol. 7, no. 4, pp. 319-327, 2006.

[11] T. Šarić, L. P. Frenzel, and J. Hescheler, "Immunological barriers to embryonic stem cell-derived therapies," Cells Tissues Organs, vol. 188, no. 1-2, pp. 78-90, 2008.

[12] D. Orlic, J. Kajstura, S. Chimenti et al., "Bone marrow cells regenerate infarcted myocardium," Nature, vol. 410, no. 6829, pp. 701-705, 2001.

[13] L. B. Balsam, A. J. Wagers, J. L. Christensen, T. Kofidis, I. L. Weissmann, and R. C. Robbins, "Haematopoietic stem cells adopt mature haematopoietic fates in ischaemic myocardium," Nature, vol. 428, no. 6983, pp. 668-673, 2004.

[14] T. Kinnaird, E. Stabile, M. S. Burnett et al., "Marrow-derived stromal cells express genes encoding a broad spectrum of arteriogenic cytokines and promote in vitro and in vivo arteriogenesis through paracrine mechanisms," Circulation Research, vol. 94, no. 5, pp. 678-685, 2004.

[15] A. A. Kocher, M. D. Schuster, M. J. Szabolcs et al., "Neovascularization of ischemic myocardium by human bonemarrow-derived angioblasts prevents cardiomyocyte apoptosis, reduces remodeling and improves cardiac function," Nature Medicine, vol. 7, no. 4, pp. 430-436, 2001.

[16] B. J. Gersh, R. D. Simari, A. Behfar, C. M. Terzic, and A. Terzic, "Cardiac cell repair therapy: a clinical perspective," Mayo Clinic Proceedings, vol. 84, no. 10, pp. 876-892, 2009.
[17] J. Rehman, J. Li, C. M. Orschell, and K. L. March, "Peripheral blood "endothelial progenitor cells" are derived from monocyte/macrophages and secrete angiogenic growth factors," Circulation, vol. 107, no. 8, pp. 1164-1169, 2003.

[18] P. Menasché, A. A. Hagège, J. T. Vilquin et al., "Autologous skeletal myoblast transplantation for severe postinfarction left ventricular dysfunction," Journal of the American College of Cardiology, vol. 41, no. 7, pp. 1078-1083, 2003.

[19] P. Menasché, O. Alfieri, S. Janssens et al., "The myoblast autologous grafting in ischemic cardiomyopathy (MAGIC) trial: first randomized placebo-controlled study of myoblast transplantation," Circulation, vol. 117, no. 9, pp. 1189-1200, 2008.

[20] P. Menasche, "Skeletal myoblasts as a therapeutic agent," Progress in Cardiovascular Diseases, vol. 50, no. 1, pp. 7-17, 2007.

[21] P. Menasche, "Skeletal myoblasts and cardiac repair," Journal of Molecular and Cellular Cardiology, vol. 45, no. 4, pp. 545553, 2008.

[22] T. Siminiak, D. Fiszer, O. Jerzykowska et al., "Percutaneous trans-coronary-venous transplantation of autologous skeletal myoblasts in the treatment of post-infarction myocardial contractility impairment: the POZNAN trial," European Heart Journal, vol. 26, no. 12, pp. 1188-1195, 2005.

[23] L. Barile, E. Messina, A. Giacomello, and E. Marbán, "Endogenous cardiac stem cells," Progress in Cardiovascular Diseases, vol. 50, no. 1, pp. 31-48, 2007.

[24] A. P. Beltrami, L. Barlucchi, D. Torella et al., "Adult cardiac stem cells are multipotent and support myocardial regeneration," Cell, vol. 114, no. 6, pp. 763-776, 2003.

[25] T. Kofidis, J. L. De Bruin, T. Yamane et al., "Insulin-like growth factor promotes engraftment, differentiation, and functional improvement after transfer of embryonic stem cells for myocardial restoration," Stem Cells, vol. 22, no. 7, pp. 1239-1245, 2004.

[26] E. Messina, L. De Angelis, G. Frati et al., "Isolation and expansion of adult cardiac stem cells from human and murine heart," Circulation Research, vol. 95, no. 9, pp. 911921, 2004.

[27] R. R. Smith, L. Barile, E. Messina, and E. Marbán, "Stem cells in the heart: what's the buzz all about?-part 1: preclinical considerations," Heart Rhythm, vol. 5, no. 5, pp. 749-757, 2008.

[28] C. Bearzi, M. Rota, T. Hosoda et al., "Human cardiac stem cells," Proceedings of the National Academy of Sciences of the United States of America, vol. 104, no. 35, pp. 14068-14073, 2007.

[29] H. Song, B. W. Song, M. J. Cha, I. G. Choi, and K. C. Hwang, "Modification of mesenchymal stem cells for cardiac regeneration," Expert Opinion on Biological Therapy, vol. 10, no. 3, pp. 309-319, 2010.

[30] K. Hochedlinger and R. Jaenisch, "Nuclear reprogramming and pluripotency," Nature, vol. 441, no. 7097, pp. 1061-1067, 2006.

[31] R. Jaenisch and R. Young, "Stem cells, the molecular circuitry of pluripotency and nuclear reprogramming," Cell, vol. 132, no. 4 , pp. 567-582, 2008.

[32] M. Nakagawa, M. Koyanagi, K. Tanabe et al., "Generation of induced pluripotent stem cells without Myc from mouse and human fibroblasts," Nature Biotechnology, vol. 26, no. 1, pp. 101-106, 2008.

[33] K. Takahashi, K. Tanabe, M. Ohnuki et al., "Induction of pluripotent stem cells from adult human fibroblasts by defined factors," Cell, vol. 131, no. 5, pp. 861-872, 2007. 
[34] S. Yamanaka, "Strategies and new developments in the generation of patient-specific pluripotent stem cells," Cell Stem Cell, vol. 1, no. 1, pp. 39-49, 2007.

[35] J. Yu, M. A. Vodyanik, K. Smuga-Otto et al., "Induced pluripotent stem cell lines derived from human somatic cells," Science, vol. 318, no. 5858, pp. 1917-1920, 2007.

[36] T. J. Nelson, A. Martinez-Fernandez, S. Yamada, C. PerezTerzic, Y. Ikeda, and A. Terzic, "Repair of acute myocardial infarction with induced pluripotent stem cells induced by human stemness factors," Circulation, vol. 120, no. 5, pp. 408-416, 2009.

[37] J. Zhang, G. F. Wilson, A. G. Soerens et al., "Functional cardiomyocytes derived from human induced pluripotent stem cells," Circulation Research, vol. 104, no. 4, pp. e30-e41, 2009.

[38] A. J. Friedenstein, R. K. Chailakhjan, and K. S. Lalykina, "The development of fibroblast colonies in monolayer cultures of guinea-pig bone marrow and spleen cells," Cell and Tissue Kinetics, vol. 3, no. 4, pp. 393-403, 1970.

[39] A. J. Friedenstein, R. K. Chailakhyan, and N. V. Latsinik, "Stromal cells responsible for transferring the microenvironment of the hemopoietic tissues. Cloning in vitro and retransplantation in vivo," Transplantation, vol. 17, no. 4, pp. 331-340, 1974.

[40] A. I. Caplan, "Molecular and cellular differentiation of muscle, cartilage, and bone in the developing limb," Progress in Clinical and Biological Research, vol. 217, pp. 307-318, 1986.

[41] A. H. Piersma, K. G. M. Brockbank, and R. E. Ploemacher, "Characterization of fibroblastic stromal cells from murine bone marrow," Experimental Hematology, vol. 13, no. 4, pp. 237-243, 1985.

[42] S. Wakitani, T. Saito, and A. I. Caplan, "Myogenic cells derived from rat bone marrow mesenchymal stem cells exposed to 5-azacytidine," Muscle and Nerve, vol. 18, no. 12, pp. 1417-1426, 1995.

[43] G. C. Kopen, D. J. Prockop, and D. G. Phinney, "Marrow stromal cells migrate throughout forebrain and cerebellum, and they differentiate into astrocytes after injection into neonatal mouse brains," Proceedings of the National Academy of Sciences of the United States of America, vol. 96, no. 19, pp. 10711-10716, 1999.

[44] S. Makino, K. Fukuda, S. Miyoshi et al., "Cardiomyocytes can be generated from marrow stromal cells in vitro," Journal of Clinical Investigation, vol. 103, no. 5, pp. 697-705, 1999.

[45] C. Toma, M. F. Pittenger, K. S. Cahill, B. J. Byrne, and P. D. Kessler, "Human mesenchymal stem cells differentiate to a cardiomyocyte phenotype in the adult murine heart," Circulation, vol. 105, no. 1, pp. 93-98, 2002.

[46] S. A. Patel, L. Sherman, J. Munoz, and P. Rameshwar, "Immunological properties of mesenchymal stem cells and clinical implications," Archivum Immunologiae et Therapiae Experimentalis, vol. 56, no. 1, pp. 1-8, 2008.

[47] K. Le Blanc, C. Tammik, K. Rosendahl, E. Zetterberg, and O. Ringdén, "HLA expression and immunologic properties of differentiated and undifferentiated mesenchymal stem cells," Experimental Hematology, vol. 31, no. 10, pp. 890-896, 2003.

[48] K. Le Blanc and O. Ringdén, "Immunobiology of human mesenchymal stem cells and future use in hematopoietic stem cell transplantation," Biology of Blood and Marrow Transplantation, vol. 11, no. 5, pp. 321-334, 2005.

[49] J. Tolar, P. Villeneuve, and A. Keating, "Mesenchymal stromal cells for graft-versus-host disease," Human Gene Therapy, vol. 22, no. 3, pp. 257-262, 2011.
[50] K. Bieback, S. Kinzebach, and M. Karagianni, "Translating research into clinical scale manufacturing of mesenchymal stromal cells," Stem Cells International, vol. 2010, Article ID 193519, 2010.

[51] L. da Silva Meirelles, P. C. Chagastelles, and N. B. Nardi, "Mesenchymal stem cells reside in virtually all post-natal organs and tissues," Journal of Cell Science, vol. 119, no. 11, pp. 2204-2213, 2006.

[52] A. I. Caplan, "Mesenchymal stem cells," Journal of Orthopaedic Research, vol. 9, no. 5, pp. 641-650, 1991.

[53] A. J. Boyle, I. K. McNiece, and J. M. Hare, "Mesenchymal stem cell therapy for cardiac repair," Methods in Molecular Biology, vol. 660, pp. 65-84, 2010.

[54] K. H. Schuleri, A. J. Boyle, and J. M. Hare, "Mesenchymal stem cells for cardiac regenerative therapy," Handbook of Experimental Pharmacology, no. 180, pp. 195-218, 2007.

[55] M. Khan, S. Meduru, R. Gogna et al., "Oxygen cycling in conjunction with stem cell transplantation induces $\mathrm{NOS}_{3}$ expression leading to attenuation of fibrosis and improved cardiac function," Cardiovascular Research, vol. 93, no. 1, pp. 89-99, 2012.

[56] J. M. Ryan, F. P. Barry, J. M. Murphy, and B. P. Mahon, "Mesenchymal stem cells avoid allogeneic rejection," Journal of Inflammation, vol. 2, article 8, 2005.

[57] K. C. Kemp, J. Hows, and C. Donaldson, "Bone marrowderived mesenchymal stem cells," Leukemia and Lymphoma, vol. 46, no. 11, pp. 1531-1544, 2005.

[58] J. M. Zimmet and J. M. Hare, "Emerging role for bone marrow derived mesenchymal stem cells in myocardial regenerative therapy," Basic Research in Cardiology, vol. 100, no. 6, pp. 471-481, 2005.

[59] M. F. Pittenger, A. M. Mackay, S. C. Beck et al., "Multilineage potential of adult human mesenchymal stem cells," Science, vol. 284, no. 5411, pp. 143-147, 1999.

[60] D. J. Prockop, I. Sekiya, and D. C. Colter, "Isolation and characterization of rapidly self-renewing stem cells from cultures of human marrow stromal cells," Cytotherapy, vol. 3, no. 5, pp. 393-396, 2001.

[61] Y. Jiang, B. N. Jahagirdar, R. L. Reinhardt et al., "Pluripotency of mesenchymal stem cells derived from adult marrow," Nature, vol. 418, no. 6893, pp. 41-49, 2002.

[62] Y. Jiang, B. Vaessen, T. Lenvik, M. Blackstad, M. Reyes, and C. M. Verfaillie, "Multipotent progenitor cells can be isolated from postnatal murine bone marrow, muscle, and brain," Experimental Hematology, vol. 30, no. 8, pp. 896-904, 2002.

[63] Y. S. Yoon, A. Wecker, L. Heyd et al., "Clonally expanded novel multipotent stem cells from human bone marrow regenerate myocardium after myocardial infarction," Journal of Clinical Investigation, vol. 115, no. 2, pp. 326-338, 2005.

[64] A. Rossini, C. Frati, C. Lagrasta et al., "Human cardiac and bone marrow stromal cells exhibit distinctive properties related to their origin," Cardiovascular Research, vol. 89, no. 3, pp. 650-660, 2011.

[65] S. Fazel, L. Chen, R. D. Weisel et al., "Cell transplantation preserves cardiac function after infarction by infarct stabilization: augmentation by stem cell factor," Journal of Thoracic and Cardiovascular Surgery, vol. 130, no. 5, p. 1310, 2005.

[66] S. Tomita, R. K. Li, R. D. Weisel et al., "Autologous transplantation of bone marrow cells improves damaged heart function," Circulation, vol. 100, no. 19, supplement, pp. II247-II256, 1999.

[67] R. W. Grauss, J. Van Tuyn, P. Steendijk et al., "Forced myocardin expression enhances the therapeutic effect of human mesenchymal stem cells after transplantation in 
ischemic mouse hearts," Stem Cells, vol. 26, no. 4, pp. 10831093, 2008.

[68] M. Kudo, Y. Wang, M. A. Wani, M. Xu, A. Ayub, and M. Ashraf, "Implantation of bone marrow stem cells reduces the infarction and fibrosis in ischemic mouse heart," Journal of Molecular and Cellular Cardiology, vol. 35, no. 9, pp. 11131119, 2003.

[69] Y. Nakamura, X. Wang, C. Xu et al., "Xenotransplantation of long-term-cultured swine bone marrow-derived mesenchymal stem cells," Stem Cells, vol. 25, no. 3, pp. 612-620, 2007.

[70] N. Noiseux, M. Gnecchi, M. Lopez-Ilasaca et al., "Mesenchymal stem cells overexpressing Akt dramatically repair infarcted myocardium and improve cardiac function despite infrequent cellular fusion or differentiation," Molecular Ther$a p y$, vol. 14, no. 6, pp. 840-850, 2006.

[71] M. Shiota, T. Heike, M. Haruyama et al., "Isolation and characterization of bone marrow-derived mesenchymal progenitor cells with myogenic and neuronal properties," Experimental Cell Research, vol. 313, no. 5, pp. 1008-1023, 2007.

[72] M. F. Berry, A. J. Engler, Y. J. Woo et al., "Mesenchymal stem cell injection after myocardial infarction improves myocardial compliance," American Journal of Physiology, vol. 290, no. 6, pp. H2196-H2203, 2006.

[73] W. Dai, S. L. Hale, B. J. Martin et al., "Allogeneic mesenchymal stem cell transplantation in postinfarcted rat myocardium: short- and long-term effects," Circulation, vol. 112, no. 2, pp. 214-223, 2005.

[74] L. M. G. de Macedo Braga, S. Lacchini, B. D. Schaan et al., "In situ delivery of bone marrow cells and mesenchymal stem cells improves cardiovascular function in hypertensive rats submitted to myocardial infarction," Journal of Biomedical Science, vol. 15, no. 3, pp. 365-374, 2008.

[75] Y. Imanishi, A. Saito, H. Komoda et al., "Allogenic mesenchymal stem cell transplantation has a therapeutic effect in acute myocardial infarction in rats," Journal of Molecular and Cellular Cardiology, vol. 44, no. 4, pp. 662-671, 2008.

[76] W. Li, N. Ma, L. L. Ong et al., "Bcl-2 engineered MSCs inhibited apoptosis and improved heart function," Stem Cells, vol. 25, no. 8, pp. 2118-2127, 2007.

[77] A. A. Mangi, N. Noiseux, D. Kong et al., "Mesenchymal stem cells modified with Akt prevent remodeling and restore performance of infarcted hearts," Nature Medicine, vol. 9, no. 9, pp. 1195-1201, 2003.

[78] Y. Miyahara, N. Nagaya, M. Kataoka et al., "Monolayered mesenchymal stem cells repair scarred myocardium after myocardial infarction," Nature Medicine, vol. 12, no. 4, pp. 459-465, 2006.

[79] N. Nagaya, T. Fujii, T. Iwase et al., "Intravenous administration of mesenchymal stem cells improves cardiac function in rats with acute myocardial infarction through angiogenesis and myogenesis," American Journal of Physiology, vol. 287, no. 6, pp. H2670-H2676, 2004.

[80] L. C. Amado, A. P. Saliaris, K. H. Schuleri et al., "Cardiac repair with intramyocardial injection of allogeneic mesenchymal stem cells after myocardial infarction," Proceedings of the National Academy of Sciences of the United States of America, vol. 102, no. 32, pp. 11474-11479, 2005.

[81] L. C. Amado, K. H. Schuleri, A. P. Saliaris et al., "Multimodality Noninvasive Imaging Demonstrates In Vivo Cardiac Regeneration After Mesenchymal Stem Cell Therapy," Journal of the American College of Cardiology, vol. 48, no. 10, pp. 2116-2124, 2006.
[82] M. Gyöngyösi, J. Blanco, T. Marian et al., "Serial noninvasive in vivo positron emission tomographic tracking of percutaneously intramyocardially injected autologous porcine mesenchymal stem cells modified for transgene reporter gene expression," Circulation, vol. 1, no. 2, pp. 94-103, 2008.

[83] M. E. Halkos, Z. Q. Zhao, F. Kerendi et al., "Intravenous infusion of mesenchymal stem cells enhances regional perfusion and improves ventricular function in a porcine model of myocardial infarction," Basic Research in Cardiology, vol. 103, no. 6, pp. 525-536, 2008.

[84] S. M. Hashemi, S. Ghods, F. D. Kolodgie et al., "A placebo controlled, dose-ranging, safety study of allogenic mesenchymal stem cells injected by endomyocardial delivery after an acute myocardial infarction," European Heart Journal, vol. 29, no. 2, pp. 251-259, 2008.

[85] K. E. Hatzistergos, H. Quevedo, B. N. Oskouei et al., "Bone marrow mesenchymal stem cells stimulate cardiac stem cell proliferation and differentiation," Circulation Research, vol. 107, no. 7, pp. 913-922, 2010.

[86] R. R. Makkar, M. J. Price, M. Lill et al., "Intramyocardial injection of allogenic bone marrow-derived mesenchymal stem cells without immunosuppression preserves cardiac function in a porcine model of myocardial infarction," Journal of Cardiovascular Pharmacology and Therapeutics, vol. 10, no. 4, pp. 225-233, 2005.

[87] M. J. Price, C. C. Chou, M. Frantzen et al., "Intravenous mesenchymal stem cell therapy early after reperfused acute myocardial infarction improves left ventricular function and alters electrophysiologic properties," International Journal of Cardiology, vol. 111, no. 2, pp. 231-239, 2006.

[88] C. M. Qi, G. S. Ma, N. F. Liu et al., "Transplantation of magnetically labeled mesenchymal stem cells improves cardiac function in a swine myocardial infarction model," Chinese Medical Journal, vol. 121, no. 6, pp. 544-550, 2008.

[89] H. C. Quevedo, K. E. Hatzistergos, B. N. Oskouei et al., "Allogeneic mesenchymal stem cells restore cardiac function in chronic ischemic cardiomyopathy via trilineage differentiating capacity," Proceedings of the National Academy of Sciences of the United States of America, vol. 106, no. 33, pp. 14022-14027, 2009.

[90] K. H. Schuleri, L. C. Amado, A. J. Boyle et al., "Early improvement in cardiac tissue perfusion due to mesenchymal stem cells," American Journal of Physiology, vol. 294, no. 5, pp. H2002-H2011, 2008.

[91] K. H. Schuleri, G. S. Feigenbaum, M. Centola et al., "Autologous mesenchymal stem cells produce reverse remodelling in chronic ischaemic cardiomyopathy," European Heart Journal, vol. 30, no. 22, pp. 2722-2732, 2009.

[92] J. G. Shake, P. J. Gruber, W. A. Baumgartner et al., "Mesenchymal stem cell implantation in a swine myocardial infarct model: engraftment and functional effects," Annals of Thoracic Surgery, vol. 73, no. 6, pp. 1919-1926, 2002.

[93] E. C. Perin, G. V. Silva, J. A. R. Assad et al., "Comparison of intracoronary and transendocardial delivery of allogeneic mesenchymal cells in a canine model of acute myocardial infarction," Journal of Molecular and Cellular Cardiology, vol. 44, no. 3, pp. 486-495, 2008.

[94] G. V. Silva, S. Litovsky, J. A. R. Assad et al., "Mesenchymal stem cells differentiate into an endothelial phenotype, enhance vascular density, and improve heart function in a canine chronic ischemia model," Circulation, vol. 111, no. 2, pp. 150-156, 2005. 
[95] H. Hamamoto, J. H. Gorman III, L. P. Ryan et al., "Allogeneic mesenchymal precursor cell therapy to limit remodeling after myocardial infarction: the effect of cell dosage," Annals of Thoracic Surgery, vol. 87, no. 3, pp. 794-801, 2009.

[96] J. M. Hill, A. J. Dick, V. K. Raman et al., "Serial cardiac magnetic resonance imaging of injected mesenchymal stem cells," Circulation, vol. 108, no. 8, pp. 1009-1014, 2003.

[97] J. J. Minguell and A. Erices, "Mesenchymal stem cells and the treatment of cardiac disease," Experimental Biology and Medicine, vol. 231, no. 1, pp. 39-49, 2006.

[98] A. J. Dick, M. A. Guttman, V. K. Raman et al., "Magnetic resonance fluoroscopy allows targeted delivery of mesenchymal stem cells to infarct borders in Swine," Circulation, vol. 108, no. 23, pp. 2899-2904, 2003.

[99] D. L. Kraitchman, A. W. Heldman, E. Atalar et al., "In vivo magnetic resonance imaging of mesenchymal stem cells in myocardial infarction," Circulation, vol. 107, no. 18, pp. 2290-2293, 2003.

[100] J. Y. Min, M. F. Sullivan, Y. Yang et al., "Significant improvement of heart function by cotransplantation of human mesenchymal stem cells and fetal cardiomyocytes in postinfarcted pigs," Annals of Thoracic Surgery, vol. 74, no. 5, pp. 1568-1575, 2002.

[101] K. K. Poh, E. Sperry, R. G. Young, T. Freyman, K. G. Barringhaus, and C. A. Thompson, "Repeated direct endomyocardial transplantation of allogeneic mesenchymal stem cells: safety of a high dose, "off-the-shelf", cellular cardiomyoplasty strategy," International Journal of Cardiology, vol. 117, no. 3, pp. 360-364, 2007.

[102] C. S. Kuo, K. Munakata, C. P. Reddy, and B. Surawicz, "Characteristics and possible mechanism of ventricular arrhythmia dependent on the dispersion of action potential durations," Circulation, vol. 67, no. 6, pp. 1356-1367, 1983.

[103] J. M. Hare, J. H. Traverse, T. D. Henry et al., "A randomized, double-blind, placebo-controlled, dose-escalation study of intravenous adult human mesenchymal stem cells (prochymal) after acute myocardial infarction," Journal of the American College of Cardiology, vol. 54, no. 24, pp. 22772286, 2009.

[104] S. L. Chen, W. W. Fang, F. Ye et al., "Effect on left ventricular function of intracoronary transplantation of autologous bone marrow mesenchymal stem cell in patients with acute myocardial infarction," American Journal of Cardiology, vol. 94, no. 1, pp. 92-95, 2004.

[105] A. R. Williams, B. Trachtenberg, D. L. Velazquez et al., "Intramyocardial stem cell injection in patients with ischemic cardiomyopathy: functional recovery and reverse remodeling," Circulation Research, vol. 108, no. 7, pp. 792-796, 2011.

[106] J. O. Jeong, J. W. Han, J. M. Kim et al., "Malignant tumor formation after transplantation of short-term cultured bone marrow mesenchymal stem cells in experimental myocardial infarction and diabetic neuropathy," Circulation Research, vol. 108, no. 11, pp. 1340-1347, 2011.

[107] M. Miura, Y. Miura, H. M. Padilla-Nash et al., "Accumulated chromosomal instability in murine bone marrow mesenchymal stem cells leads to malignant transformation," Stem Cells, vol. 24, no. 4, pp. 1095-1103, 2006.

[108] M. Breitbach, T. Bostani, W. Roell et al., "Potential risks of bone marrow cell transplantation into infarcted hearts," Blood, vol. 110, no. 4, pp. 1362-1369, 2007.

[109] T. Freyman, G. Polin, H. Osman et al., "A quantitative, randomized study evaluating three methods of mesenchymal stem cell delivery following myocardial infarction," European Heart Journal, vol. 27, no. 9, pp. 1114-1122, 2006.

[110] P. R. Vulliet, M. Greeley, S. M. Halloran, K. A. MacDonald, and M. D. Kittleson, "Intra-coronary arterial injection of mesenchymal stromal cells and microinfarction in dogs," The Lancet, vol. 363, no. 9411, pp. 783-784, 2004.

[111] K. Jaquet, K. T. Krause, J. Denschel et al., "Reduction of myocardial scar size after implantation of mesenchymal stem cells in rats: what is the mechanism?" Stem Cells and Development, vol. 14, no. 3, pp. 299-309, 2005.

[112] E. H. Yao, Y. Yu, and N. Fukuda, "Oxidative stress on progenitor and stem cells in cardiovascular diseases," Current Pharmaceutical Biotechnology, vol. 7, no. 2, pp. 101-108, 2006.

[113] P. Pelegrin and A. Surprenant, "Dynamics of macrophage polarization reveal new mechanism to inhibit IL-1beta release through pyrophosphates," EMBO Journal, vol. 28, no. 14, pp. 2114-2127, 2009.

[114] D. Sáenz-Morales, E. Conde, M. M. Escribese et al., "ERK1/2 mediates cytoskeleton and focal adhesion impairment in proximal epithelial cells after renal ischemia," Cellular Physiology and Biochemistry, vol. 23, no. 4-6, pp. 285-294, 2009.

[115] W. G. Zhu, S. Li, L. Q. Lin, H. Yan, T. Fu, and J. H. Zhu, "Vascular oxidative stress increases dendritic cell adhesion and transmigration induced by homocysteine," Cellular Immunology, vol. 254, no. 2, pp. 110-116, 2009.

[116] D. E. Ingber, "Mechanical signaling and the cellular response to extracellular matrix in angiogenesis and cardiovascular physiology," Circulation Research, vol. 91, no. 10, pp. 877$887,2002$.

[117] L. A. Mylotte, A. M. Duffy, M. Murphy et al., "Metabolic flexibility permits mesenchymal stem cell survival in an ischemic environment," Stem Cells, vol. 26, no. 5, pp. 13251336, 2008.

[118] N. G. Frangogiannis, "Targeting the inflammatory response in healing myocardial infarcts," Current Medicinal Chemistry, vol. 13, no. 16, pp. 1877-1893, 2006.

[119] Y. Guo, J. He, J. Wu et al., "Locally overexpressing hepatocyte growth factor prevents post-ischemic heart failure by inhibition of apoptosis via calcineurin-mediated pathway and angiogenesis," Archives of Medical Research, vol. 39, no. 2, pp. 179-188, 2008.

[120] J. Y. Hahn, H. J. Cho, H. J. Kang et al., "Pre-treatment of mesenchymal stem cells with a combination of growth factors enhances gap junction formation, cytoprotective effect on cardiomyocytes, and therapeutic efficacy for myocardial infarction," Journal of the American College of Cardiology, vol. 51, no. 9, pp. 933-943, 2008.

[121] Z. Pasha, Y. Wang, R. Sheikh, D. Zhang, T. Zhao, and M. Ashraf, "Preconditioning enhances cell survival and differentiation of stem cells during transplantation in infarcted myocardium," Cardiovascular Research, vol. 77, no. 1, pp. 134-142, 2008.

[122] R. Ray, N. M. Novotny, P. R. Crisostomo, T. Lahm, A. Abarbanell, and D. R. Meldrum, "Sex steroids and stem cell function," Molecular Medicine, vol. 14, no. 7-8, pp. 493-501, 2008.

[123] Y. J. Yang, H. Y. Qian, J. Huang et al., "Atorvastatin treatment improves survival and effects of implanted mesenchymal stem cells in post-infarct swine hearts," European Heart Journal, vol. 29, no. 12, pp. 1578-1590, 2008.

[124] M. Khan, S. Meduru, I. K. Mohan et al., "Hyperbaric oxygenation enhances transplanted cell graft and functional 
recovery in the infarct heart," Journal of Molecular and Cellular Cardiology, vol. 47, no. 2, pp. 275-287, 2009.

[125] M. Gnecchi, H. He, N. Noiseux et al., "Evidence supporting paracrine hypothesis for Akt-modified mesenchymal stem cell-mediated cardiac protection and functional improvement," FASEB Journal, vol. 20, no. 6, pp. 661-669, 2006.

[126] A. Maurel, K. Azarnoush, L. Sabbah et al., "Can cold or heat shock improve skeletal myoblast engraftment in infarcted myocardium?” Transplantation, vol. 80, no. 5, pp. 660-665, 2005.

[127] C. Bao, J. Guo, G. Lin, M. Hu, and Z. Hu, "TNFR genemodified mesenchymal stem cells attenuate inflammation and cardiac dysfunction following MI," Scandinavian Cardiovascular Journal, vol. 42, no. 1, pp. 56-62, 2008.

[128] Z. Cheng, L. Ou, X. Zhou et al., "Targeted migration of mesenchymal stem cells modified with CXCR4 gene to infarcted myocardium improves cardiac performance," Molecular Therapy, vol. 16, no. 3, pp. 571-579, 2008.

[129] F. Gao, T. He, H. B. Wang et al., "A promising strategy for the treatment of ischemic heart disease: mesenchymal stem cellmediated vascular endothelial growth factor gene transfer in rats," Canadian Journal of Cardiology, vol. 23, no. 11, pp. 891898, 2007.

[130] T. A. Markel, Y. Wang, J. L. Herrmann et al., "VEGF is critical for stem cell-mediated cardioprotection and a crucial paracrine factor for defining the age threshold in adult and neonatal stem cell function," American Journal of Physiology, vol. 295, no. 6, pp. H2308-H2314, 2008.

[131] R. Matsumoto, T. Omura, M. Yoshiyama et al., "Vascular endothelial growth factor-expressing mesenchymal stem cell transplantation for the treatment of acute myocardial infarction," Arteriosclerosis, Thrombosis, and Vascular Biology, vol. 25, no. 6, pp. 1168-1173, 2005.

[132] J. Shujia, H. K. Haider, N. M. Idris, G. Lu, and M. Ashraf, "Stable therapeutic effects of mesenchymal stem cell-based multiple gene delivery for cardiac repair," Cardiovascular Research, vol. 77, no. 3, pp. 525-533, 2008.

[133] H. Song, W. Chang, S. Lim et al., "Tissue transglutaminase is essential for integrin-mediated survival of bone marrowderived mesenchymal stem cells," Stem Cells, vol. 25, no. 6, pp. 1431-1438, 2007.

[134] H. Song, K. Kwon, S. Lim et al., "Transfection of mesenchymal stem cells with the FGF-2 gene improves their survival under hypoxic conditions," Molecules and Cells, vol. 19, no. 3, pp. 402-407, 2005.

[135] S. W. Song, W. Chang, B. W. Song et al., "Integrin-linked kinase is required in hypoxic mesenchymal stem cells for strengthening cell adhesion to ischemic myocardium," Stem Cells, vol. 27, no. 6, pp. 1358-1365, 2009.

[136] J. Yang, W. Zhou, W. Zheng et al., "Effects of myocardial transplantation of marrow mesenchymal stem cells transfected with vascular endothelial growth factor for the improvement of heart function and angiogenesis after myocardial infarction," Cardiology, vol. 107, no. 1, pp. 17-29, 2006.

[137] B. Zeng, H. Chen, C. Zhu, X. Ren, G. Lin, and F. Cao, "Effects of combined mesenchymal stem cells and heme oxygenase1 therapy on cardiac performance," European Journal of Cardio-thoracic Surgery, vol. 34, no. 4, pp. 850-856, 2008.

[138] H. B. Houbaviy, M. F. Murray, and P. A. Sharp, "Embryonic stem cell-specific microRNAs," Developmental Cell, vol. 5, no. 2, pp. 351-358, 2003.
[139] H. B. Houbaviy, L. Dennis, R. Jaenisch, and P. A. Sharp, "Characterization of a highly variable eutherian microRNA gene," RNA, vol. 11, no. 8, pp. 1245-1257, 2005.

[140] M. R. Suh, Y. Lee, J. Y. Kim et al., "Human embryonic stem cells express a unique set of microRNAs," Developmental Biology, vol. 270, no. 2, pp. 488-498, 2004.

[141] K. A. O’Donnell, E. A. Wentzel, K. I. Zeller, C. V. Dang, and J. T. Mendell, "c-Myc-regulated microRNAs modulate E2F1 expression," Nature, vol. 435, no. 7043, pp. 839-843, 2005.

[142] A. Ventura, A. G. Young, M. M. Winslow et al., "Targeted deletion reveals essential and overlapping functions of the miR-17 92 family of miRNA clusters," Cell, vol. 132, no. 5, pp. 875-886, 2008.

[143] L. He, J. M. Thomson, M. T. Hemann et al., "A microRNA polycistron as a potential human oncogene," Nature, vol. 435, no. 7043, pp. 828-833, 2005.

[144] V. K. Gangaraju and H. Lin, "MicroRNAs: key regulators of stem cells," Nature Reviews Molecular Cell Biology, vol. 10, no. 2, pp. 116-125, 2009.

[145] N. Tano, H. W. Kim, and M. Ashraf, "MicroRNA-150 regulates mobilization and migration of bone marrowderived mononuclear cells by targeting Cxcr4," PLoS ONE, vol. 6, no. 10, article e23114, 2011.

[146] C. E. Murry, L. J. Field, and P. Menasché, "Cell-based cardiac repair reflections at the 10-year point," Circulation, vol. 112, no. 20, pp. 3174-3183, 2005.

[147] K. Bieback, V. A. T. Ha, A. Hecker et al., "Altered gene expression in human adipose stem cells cultured with fetal bovine serum compared to human supplements," Tissue Engineering-Part A, vol. 16, no. 11, pp. 3467-3484, 2010.

[148] G. Lepperdinger, R. Brunauer, A. Jamnig, G. Laschober, and M. Kassem, "Controversial issue: is it safe to employ mesenchymal stem cells in cell-based therapies?" Experimental Gerontology, vol. 43, no. 11, pp. 1018-1023, 2008.

[149] L. W. Miller, "Stem cell therapy trials: a call for standardization," Journal of Cardiovascular Translational Research, vol. 1, no. 3, pp. 185-187, 2008.

[150] C. Nesselmann, N. Ma, K. Bieback et al., "Mesenchymal stem cells and cardiac repair," Journal of Cellular and Molecular Medicine B, vol. 12, no. 5, pp. 1795-1810, 2008.

[151] D. G. Katritsis, P. A. Sotiropoulou, E. Karvouni et al., "Transcoronary transplantation of autologous mesenchymal stem cells and endothelial progenitors into infarcted human myocardium," Catheterization and Cardiovascular Interventions, vol. 65, no. 3, pp. 321-329, 2005.

[152] D. G. Katritsis, P. Sotiropoulou, E. Giazitzoglou, E. Karvouni, and M. Papamichail, "Electrophysiological effects of intracoronary transplantation of autologous mesenchymal and endothelial progenitor cells," Europace, vol. 9, no. 3, pp. 167$171,2007$.

[153] M. Mohyeddin-Bonab, M. R. Mohamad-Hassani, K. Alimoghaddam et al., "Autologous in vitro expanded mesenchymal stem cell therapy for human old myocardial infarction," Archives of Iranian Medicine, vol. 10, no. 4, pp. 467-473, 2007.

[154] J. Bartunek, D. Wijns, M. Dolatabadi et al., "C-cure multicenter trial: lineage specified bone marrow derived cardiopoietic mesenchymal stem cells for treatment of ischemic cardiomyopathy," Journal of the American College of Cardiology, vol. 57, article 200, 2011. 

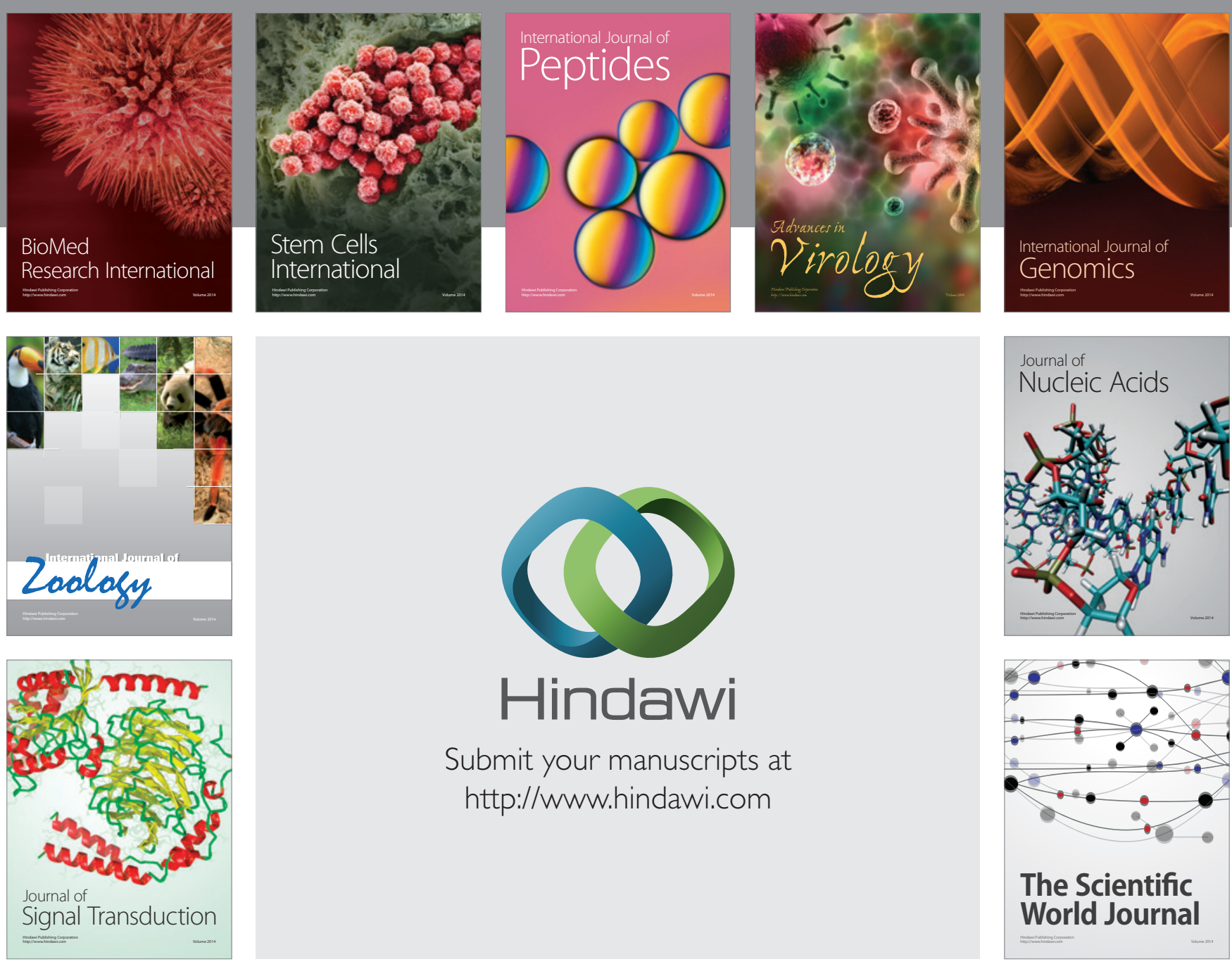

Submit your manuscripts at

http://www.hindawi.com
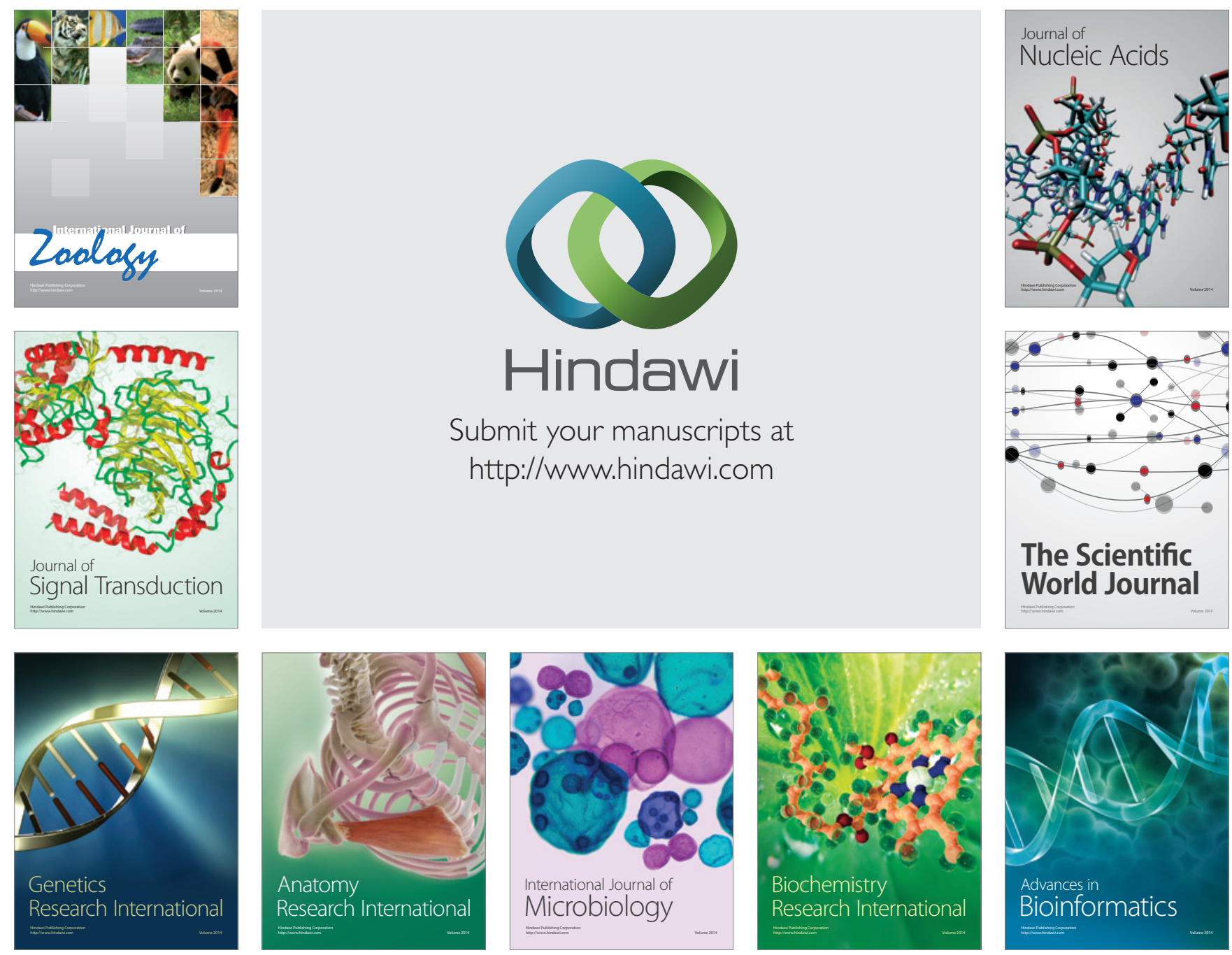

The Scientific World Journal
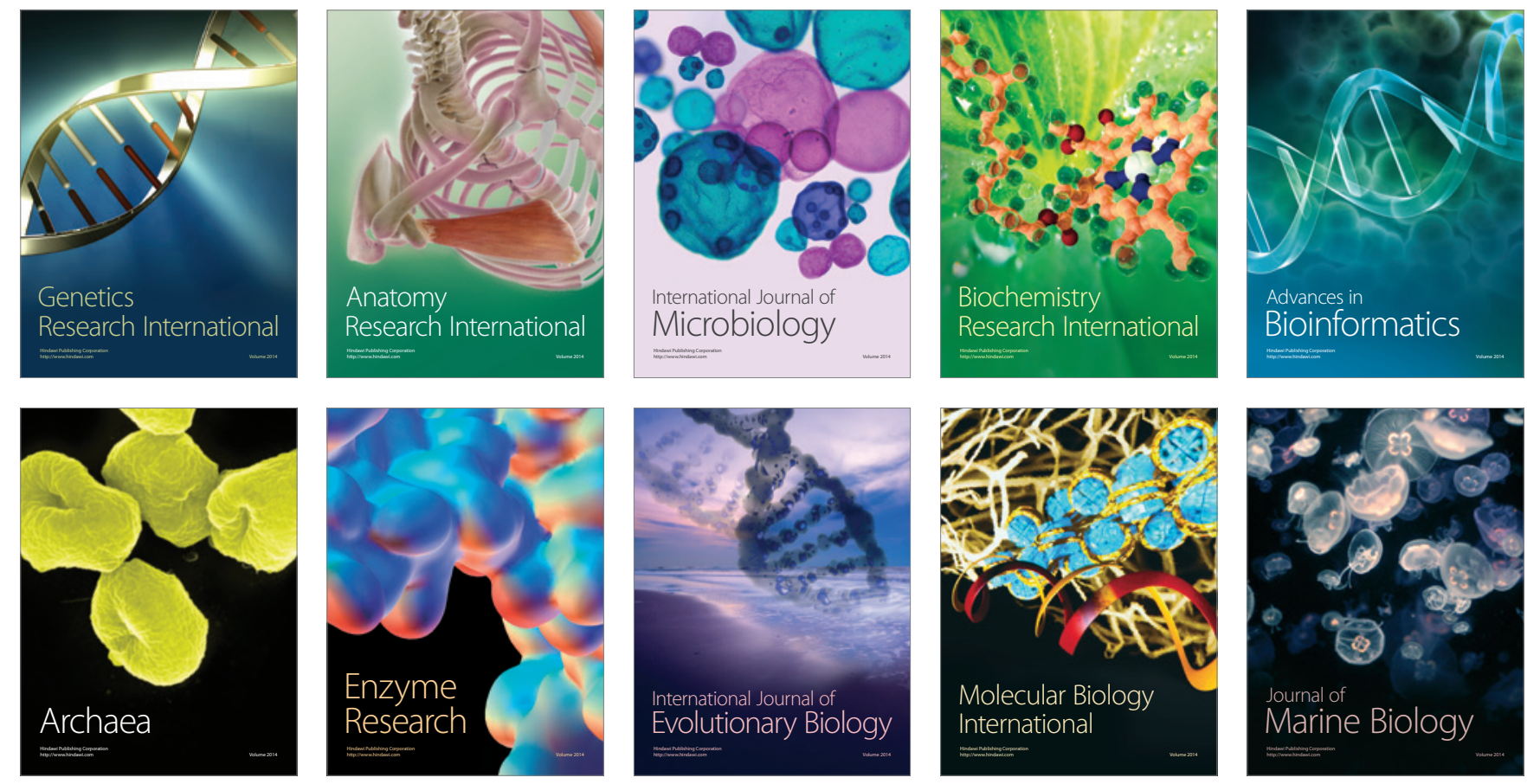